\title{
About using ficion and film in gender education
}

\author{
Ingrid Persson and Karin Persson
}

\section{Linköping University Post Print}

\section{Tweet}

N.B.: When citing this work, cite the original article.

Original Publication:

Ingrid Persson and Karin Persson, About using ficion and film in gender education, 2013, Journal of Contemporary Medical Education, (1), 2, 100-105.

http://dx.doi.org/10.5455/jcme.20130220110635

Copyright: Scopemed

http://www.scopemed.org/

Postprint available at: Linköping University Electronic Press

http://urn.kb.se/resolve?urn=urn:nbn:se:liu:diva-95613 


\title{
Journal of Contemporary Medical Education
}

\author{
available at www.scopemed.org
}

\section{Original Research}

\section{About using fiction and film in gender education}

\author{
Ingrid A-L Persson, Karin Persson
}

Department of Medical and Health Sciences, Division of Drug Research, Linköping University

\begin{abstract}
Received: November 21, 2012
Accepted: February 20, 2013

Published Online: April 12, 2013

DOI: $10.5455 / \mathrm{jcme} .20130220110635$

Corresponding Author:

Karin Persson,

Linköping University, Linköping, SWEDEN

karin.persson@liu.se

Keywords: Fiction, film, gender, higher education

ABSTRACT

Gender, male and female has always been of great interest and present in almost all fiction and films, within different perspectives. Ever since the dawn of time, man has taught ethics, morals, values and existential questions using fictional stories in oral and later in written form. The aim of analyzing the concept of male and female from fiction and film is to reach deeper insight and understanding of human beings with special reference to gender in both individual, group and community perspective. The general aim is to create security in our gender and professional roles. Whole or parts of books and films are used, chosen according to the specific learning outcome. Different aspects are then discussed in lectures, seminars or groups. Aspects include projections, culture and behavior. Students learn to reach a deeper insight and understanding of gender regarding behavior, communication, attitudes, values, culture and ethnicity. Peeling off the illusion of male and female created by our social structure, and making our values and prejudices conscious, we might discern the eternally human, the inner core of being human, regardless of sex. Fiction and film make conscious behavior, communication and gender, and merge cognition and emotions. This way of teaching may lead to better treatment of patients by health care personnel.
\end{abstract}

(C) 2013 GESDAV

\section{INTRODUCTION}

"A home without books is a body without soul"

Marcus Tullius Cicero

"No form of art goes beyond ordinary consciousness as film does, straight to our emotions, deep into the twilight room of the soul"

Ingmar Bergman

\section{A Fairy Tale Joining The Conscious And Subconscious}

Ever since the dawn of time, man has taught ethics, moral, values and existential matters through fictive stories in oral and later also in written form. Myths and fairy tales have always been a means to communicate knowledge and traditions, empathy and understanding, as a part of our education in self-awareness, a kind of initiation ritual [1]. These, in the beginning myths, legends and fairy tales, have then developed into the fiction and film of our time.

The fiction speaks directly to us on a deeper level, offering time and space for reflection while leaving the individual outside of the actual events. Myths, dreams, fairy tales, fiction and film have in common that they capture to us the invisible dimension, what we cannot see. Narrative images are original forms that go directly to our subconscious and touch us emotionally. Fiction connects thought/cognition with our emotions; body and soul is integrated, joining our conscious and unconscious conceptions of the surrounding world and ourselves [2]. 
Fiction and film have for a number of years been used in education of further health care personnel in various countries [3-7]. This article describes the method used to implement fiction and film in the education of future health care personnel at the Faculty of Health Sciences, Linköping University, with special reference to gender education.

\section{Male and Female}

Gender and sex can, and have been, studied from several different perspectives depending on profession e.g. geneticists, sociologists, psychologists or historians. For instance, some claim that the difference between man and woman is to be found in our genome, while others mean that all men and women are a mixture of male and female, "neither man or woman". This means, that female traits can be found in a man just as male traits in a woman. Depending on a historical, cultural or social context, the male aspect may overcome the female (patriarchy), or vice versa (matriarchy). The question of patriarchy and/or matriarchy indicates that the difference between male and female not entirely is a question of sex, but more like a balance between male and female. This concept of balance between genders also includes equality and equal opportunities as gender refers to the socially constructed roles, behavior, activities and attitudes that society and cultures consider appropriate for men and women, the concept of masculine and feminine. What is considered to be masculine and/or feminine has varied during the pass of time, society and to each individual. Humans have created and obtained cultural and individual values and conceptions of male and female. Values and conceptions affect work, in e.g. the health care system. All humans have visible (conscious) as well as hidden (unconscious) values and conceptions that are acted upon in conscious and unconscious behavior and in communication and attitudes. Health care personnel bring these hidden values and created illusions into the clinic, into dialogue and care of the patients, into the microscope, into the cell samples. This might lead to inequalities in treatment. Important issues to clarify are if our hidden values and conceptions of gender are imbedded in the questions put to the patients and in the interpretation of responses and observations? How do we use our values and conceptions of male and female? How do we spread these conceptions? University teachers may also bring them into the lecture halls when teaching future health care personnel. Making unspoken patterns, projections and hidden values visible to the individual already during the education of future health care personnel would improve patient care and prevent inequalities. Inequalities can lead to inequalities in treatment on a conscious and/or unconscious level.
Lack of knowledge/consciousness about the "true" and equal nature of male and female creates psychic tension within ourselves, tension in the form of energy. This inner energy can be projected on the surroundings or be stored in the unconscious of individuals and/or society and affecting behavior and profession. This is well described in fiction and film. The tension and projections inside a person and also between individuals may lead to conflicts resulting in security and peace as in the film Red Beard [8] a film describing the tyrannical, but as is seen late in the film, compassionate doctor and his trainee; suffering can be soothed with compassion and humility. Or, the result of tension and projections can lead to infectious disorder as in Doctor Glas by the Swedish author Hjalmar Söderberg (1905, translated to English in 1963) [9]. Doctor Glas is the main character in this book, a physician dealing with moral and love issues towards a patient which all end up in destruction.

The purpose of using fiction and film in education is to avoid and complement the often one-dimensional image of mankind that is conveyed in medical and nursing programs, and to uncover the hidden inner dimensions and nuances in the description of gender. Fiction and film are used as a mean and tool to express and understand all dimensions of male and female. In fiction and film we take part of various ideas and concurrently seek for, make conscious and question values and conceptions of our own and others' individual view of male and female [2].

\section{METHODS}

To conceive our unconscious values, prejudices and emotions, it is important that fiction and film is not only discussed (talked about) from the outer perceived views of the story but also analyzed (carefully examined) from within the hidden expressions. To reach these hidden expressions you may analyze all aspects of gender; gender in its sexual, social, cultural, ethnical, political and religious perspective, including power, equality, gender, discrimination and personal development. Whole or parts of books and films have been used depending on the specific learning outcome. In the latter situation, teachers may show the scene or read the paragraph at a lecture to emphasize facts conveyed and spontaneous discussion may develop. When whole books/films are used, students read/watch at home and present their conclusions at tutor-led seminars or groups. Here, different groups of students may get different phenomena or aspects to observe e $g$ projections, physiology or archetypes. In PBL, students process scenarios of different types, for example case studies of patients. As examples, chapter(s) from a book or scene(s) from a movie could be used as scenario. 
To acquire a meaningful education the aims should be clearly stated; in other words, specific learning outcomes formulated in the syllable and conveyed to the students. If this method solely is used for superficial discussions and the connection to learning outcomes is weak, there is a risk that the students experience the education as "foggy" or maybe pointless. In education, the teacher can focus on either the female or the male or both, and choose fiction and/or film accordingly.

Below are listed suggested aspects to analyze including examples of film or fiction:

- The historical context i.e. social structure, spirit, intellectual, cultural, ethnical, religious and political movements of the specific time. Example: Vera Drake [10], and Water [11].

- The life cycle according to growth, life changes and influence of the surroundings (environment). Example: Siddharta by Herman Hesse [12] and The Piano Tuner by Daniel Mason [13].

- Symbols i.e. how concrete and abstract concepts are used to describe the life cycle e.g. colors, lighting, music, props, what words represent, the Shadow, the collective unconsciousness, alchemical symbols. Examples are found in all fiction and film mentioned in the article.

- Behavior, e.g. actions, body language and voice in a psychological, social, cultural, economic and political perspective. Examples are found in all fiction and film mentioned in the article.

- Psychological defense mechanisms to find underlying motives, mainly projections. Example: Como agua para chocolate [14].

- The heroic myth. Identification of the hero or antihero and thereby identification of the adventures and experiences he/she is facing. Examples: The Piano Tuner by Daniel Mason [13] and Thelma and Louise [15].

- The interpretation of the work. The author's influence on the work and/or the interpretation made by the director or the producer. Examples: films directed by Ingmar Bergman.

Based on this, we can explore and make conscious the aspects, emotions and values of genus on individual, group and community levels.

We remind teachers to consider the law of copyright!

\section{“Zapping” Between Channels}

Here follows examples of fiction and film to use in education about gender. These short descriptions are intended to act as inspiration and rouse curiosity without directing the reader's own analysis, a zapping between channels in order to give rise to interest and curiosity.

\section{Once Upon a Time, There was a Mother and Her Three Daughters}

Once upon a time... there was, as in the fairy tale or dream, in the timeless eternity, a mother and her three daughters. The father was dead due to his weakness, as his manliness was questioned. Como agua para chocolate [14] is a movie about the unification of male and female, fire and water, the warrior and the amazon. This movie also concerns strong emotions, projections, change and growth, the pure male aspect controlled by instincts/drive and the pure female in its physical nakedness. The film ends as it begins, the circle is complete and the process starts all over again in all eternity; once upon a time...

During the $19^{\text {th }}$ century the role of the woman was under discussion and change. It was stated that male and female features were not biologically determined but created within the social environment and thereby changeable. The play "A Doll's House" 1879 by the Norwegian writer Henrik Ibsen [16] describes the female role in marriage. Nora lives a seemingly perfect marriage that eventually turns out to be a lifelong lie.

Julie, in Miss Julie 1888 by August Strindberg [17], is brought up to think and act like a man, knows how to get what she desires, but do not know what she desires. Julie is a very confused individual.

The discussion about the role of woman continues.

Thelma and Louise [15] and Lieutenant Ripley in Alien [18] exemplify the aggressive woman. These movies show women taking the law into their own hands and shooting men in self-defense; ancient (but modern) types of women appear on stage, the witches and "shemonsters" are jumping out of their hiding places.

\section{“I can't see any women, just lots of lizards"}

In parallel to the development of the woman and the role of woman is the role and the development of the man. In the book Silk by Allessandro Baricco [19], we follow Hervé Jocour to Japan. This is a timeless story, a fairy tale for adults about a lost man, an illusion, a great love, a journey, longing and self-insight and a meeting with an alien culture.

In The Magus by John Fowles [20], we pursue the teacher Nicholas Urfe to Greece. The book is describing a young man and his self-awareness, the border between fantasy and reality is blurred.

In the movie Master and Commander - the Far Side of the World [21], a film with only male actors, the audience follows Captain Jack Aubrey and his crew in 
the struggle with a Napolitano vessel. The film is about men and all actors are men, but the female presence can be perceived through the entire film. The female aspect is present in the ship, the captain's letters and the photograph of his wife, the music and the nature of the Galapagos Islands.

"I can't see any women, just lots of lizards."

"What? No women? It ain't natural."

Womanhood is discerned in various shapes with the aim to accentuate and glorify, and/or to complete the male.

\section{One does not Exist Without the Other}

Male and female can be found in all films and fiction, hidden or visible; in films with only men or in films with only women. Fiction and film can be used to identify all nuances of male and female. There are as many nuances as there are individuals. Concomitantly with our separation of male and female, they exist weaved into each other; one does not exist without the other. There has always been, and will always be an interaction between male-female, male-male, femalemale and female-female. We use and need the male and female to make ourselves visible as men and women, as human beings.

The film Der kriger und die Keiserin [22] is a suggestive experience about Sissi and Bodo, brought together by... destiny? In this film, the individuals are in focus, neither sex nor gender, neither male nor female, but individuals.

The African Queen [23], is a film about the man Charlie Allnutt and the woman Rose Sayer living together in the same country but still in different worlds. The First World War starts and stranded on the boat The African Queen they try to escape the dangers of the war and the nature to finally through prayer ask God for help. The film associates to Homer's Odyssey. The World War is not the only war described in the movie. On the river of life, the viewers follow the war between sexes, a meeting of opposites: Charlie-Rose, man-woman, alcohol-tea, profane-religious.... dialogues, arguments and discussions in order to together strive towards surrender of the opposite gender and survival of them both.

"I do not regret a thing. It was worth it", Charlie says.

In the film we meet fear and joy when discovering that we actually love each other, and love to experience adventures together as in any marriage. It takes courage, hard work and self-insight to distinguish and merge our concepts of male and female.

\section{RESULT AND DISCUSSION}

In medical professions, knowledge is mainly acquired of the physiological body. We pursue a thought-based teaching. However, we must not forget that the context the body works in and the image we have created of male and female on individual, group and community levels are present in our daily work. The learning outcomes include that the students are to reach deeper insight and understanding of human beings regarding behavior, communication, attitudes, values, culture, ethnicity and gender in both individual, group and community perspective, as well as to develop a professional policy by reflecting on their own values, attitudes and views of people. Human beings are not only the taught scientific function of physiology and thought, but also emotional experiences, attitudes and values. The intellect often overlooks emotional factors, but emotions and feelings are essential to life and survival and belong to our person and identity. The emotional factor plays an essential part when we are studying and trying to understand the total multidimensional human being. For health care personnel to understand the entire human, increased knowledge and education of the intertwined body and soul is of great importance. The aspect of thought shows the structure while the emotions represent our values. The aspects of thought and emotions together provide a synergistic use of our brain and we may use this synergism to achieve a steadfast value of the balance between male and female. Fiction and film describe conscious experiences, everything that occur in human daily life, often strong experiences as powerful emotions, suffering and passion. Human daily life, human eternal destiny, where joy and sorrow are captured, described and made visible in rational, structured words and images. Furthermore, fiction and film convey what we cannot understand or capture with our mind/thoughts, i.e. our emotions/feelings. When we read fiction or watch films the unconscious takes control and the onlooker emerges into the story without understanding how. Emotions are arisen and activated, and we can rewind and repeat to understand the connection to our inner self. The power of fiction and film lies in the power of our emotions. As for example in the movie Brief encounter [24] where the love between Laura and Alec describes the conscious experience (we are all aware of the emotions of love), while the motive for love describes the unconscious emotions.

\section{The encounter between the inner and the outer reality}

There is probably no common universal principle or description of male/masculinity and female/femininity. 
Instead we have to clarify how and why we create our individual, social and cultural experience of man and woman, and how this experience is manifested and lived. One way to obtain clarity is to reflect/mirror ourselves in fiction and film, and in this reflection meet the illusion of our own individual and social experience. To reflect ourselves in the men, women and gender of film and fiction is to participate in emotions and dreams without letting the intellect filter the content. The important issue is the encounter between the outer and inner reality.

Two truths approach each other. One comes from within,

One comes from without - and where they meet you have the chance to catch a look at yourself.

Tomas Tranströmer, Preludes II (Seventeen Poems for the Living and Dead) [25].

This is a poem seeking unity of the relationship between the inner and the outer reality. There we get an opportunity to experience what could be called the truth about ourselves, our thoughts, emotions and values of male and female. Our striving, wishes, dreams and hopes are reflected in fiction and films. What does your mirror reflect? Is it the subservient attitudes as in Memoirs of a Geisha by Arthur Golden [26], or is it the striving for equality as in The Piano [27]? Or, is it the almost unattainable as in...???

Analyzing fiction and film in this way in education is a challenge for both teachers and students as it requires an open mind to increased self-insight. To reach optimal results the teachers' competence in using fiction and film in education is of uttermost importance. We recommend teachers and tutors to acquire, apart from knowledge of their specific field, basic knowledge/experience of human psychology and behavioral sciences; this to avoid shallow discussions. One way of achieving this is supplying the teacher with a mentor; another way is that teachers in groups train to analyze. The challenge of the students is to have the courage to process the knowledge on a psychological level deep enough to achieve the learning outcomes, without making it a therapy session.

\section{CONCLUSION}

The value of using fiction and film in education is in their transferring of the psychological tension reflected in the interaction between the outer and inner reality. This tension is a result of social expectations, rules and inherited behavior. Peeling off the illusion of male and female created by our social structure, and making our values and prejudices conscious, we might discern the eternally human, the inner core of being human, regardless of sex. This can be done through discussion, but above all through analyzing the concept of male and female over time and culture. Fiction and film are excellent tools in the education of gender. They make conscious behavior, communication and gender, and merge cognition and emotions. The general aim is to create security in our gender and professional roles, and to improve the treatment of patients. The choice of book or film should be made according to specific aim or learning outcome, but also inclination and taste. The method is based upon an analysis of both outer, but perhaps foremost inner events in the pieces. Fiction and film leave no one unaffected.

\section{REFERENCES}

1. Von Franz ML. Interpretation of fairytales. Kösel-Verlag, Munich, Germany, 1986.

2. Tucker M. Dreaming with open eyes. Aquarian/Harper, San Francisco, USA, 1993.

3. Persson IA-L, Persson K. Fiction and film as teaching instruments in higher health care education. Journal of Further and Higher Education 2008;32(2):111-18.

4. Kalra G. Teaching diagnostic approach to a patient through cinema. Epilepsy \& Behavior 2011;22:571-73.

5. Kalra G. Talking about stigma towards mental health professionals with psychiatry trainees: A movie club approach. Asian Journal of Psychiatry 2012;5:266-68.

6. Deaking N, Bhugra D. Families in Bollywood cinema: changes and context. International Review of Psychiatry 2012;24(2):166-72.

7. Bhugra D, Gupta S. Psychoanalysis and the Hindi cinema. International Review of Psychiatry 2009;21(3): $234-40$.

8. Toho. Red Beard. Produced by Ryuzo Kikushima and Tomoyuki Tanaka; Directed by Akira Kurosawa, 1965.

9. Söderberg H. Doctor Glas. Albert Bonniers Förlag, Stockholm, Sweden, 1905.

10. Optimum Releasing. Vera Drake. Produced by Simon Channing-Williams, Directed by Mike Leigh, 2004.

11. Fox Searchlight Pictures. Water. Produced by David Hamilton, Directed by Deepa Mehta, 2005.

12. Hesse H. Siddhartha. Eine indische Dichtung. S. Fischer Verlag, Frankfurt am Main, Germany, 1922.

13. Mason D. The Piano Tuner. Vintage Books, UK, 2002.

14. Arau Films International, S.A. Como agua para chocolate. Produced by Alfonso Arau, Directed by Alfonso Arau, 1992.

15. Metro-Goldwyn-Mayer. Thelma and Louise. Produced by Mimi Polk Gitlin and Ridley Scott, Directed by Ridley Scott, 1991.

16. Ibsen H. A Doll's House. Premiered at The Royal Theatre in Copenhagen, Denmark, 1879. 
17. Strindberg A. Miss Julie. Premiered at The Scandinavian Experimental Theatre in Copenhagen, Denmark, 1888.

18. $20^{\text {th }}$ Century Fox. Alien. Produced by Gordon Carroll, David Giler and Water Hill, Directed by Ridley Scott, 1979.

19. Barricco A. Silk. Harvill Press, London, UK, 1996.

20. Fowles J. The Magus. Little Brown, UK, 1966.

21. $20^{\text {th }}$ Century Fox. Master and Commander. Produced by Alan B Curtiss, Directed by Peter Weir, 2003.

22. Sony Pictures Classics. Der Kriger und die Keiserin. Produced by Stefan Arndt, Katja De Bock, Gebhard Henke and Maria Köpf, Directed by Tom Tykwer, 2000.
23. United Artists. The African Queen. Produced by Sam Spiegel and John Woolf, Directed by John Huston, 1951.

24. Eagle-Lion Distributors. Brief Encounter. Produced by Noël Coward, Anthony Havelock-Allan, David Lean and Ronald Neame, Directed by David Lean, 1945.

25. Tranströmer T. Seventeen Poems. Albert Bonniers Förlag, Stockholm, Sweden, 1954.

26. Golden A. Memoirs of a Geisha. Alfred A Knopf, New York, USA, 1997.

27. Miramax. The Piano. Produced by Jan Chapman, Directed by Jane Campion, 1993.

This is an open access article licensed under the terms of the Creative Commons Attribution Non-Commercial License which permits unrestricted, non-commercial use, distribution and reproduction in any medium, provided the work is properly cited. 